\title{
Сучасні погляди на патогенетичні механізми формування віддалених наслідків легкої закритої черепно-мозкової травми
}

\author{
Є.В. Лекомцева \\ Державна установа «Інститут неврології, психіатрії та наркології Національної академії медичних наук України», Харків, Україна
}

\begin{abstract}
Анотація. Стаття присвячена вивченню комплексних патогенетичних механізмів формування віддалених наслідків після перенесеної легкої закритої черепно-мозкової травми. Представлені сучасні та узагальнені дані щодо етіопатогенезу, патоморфології та особливостей нейробіохімічних метаболічних порушень, зокрема клінічні та експериментальні дані щодо стану вільнорадикальних реакцій перекисного окиснення ліпідів, глутаматергічної та антиоксидантної систем у цієї категорії хворих, викладені сучасні принципи ранньої діагностики даної патології. Розглянуто механізми розвитку неконтрольованої інтенсифікації перекисного окиснення ліпідів, яка відбувається в умовах порушення рівноваги між процесами пероксидації та активністю антиоксидантної системи. Наявні дослідження також демонструють високе значення оксидантно-антиоксидантних взаємовідносин у формуванні енергетичного дефіциту та пошкоджені нейронних мембран у віддалений період після нейротравми.
\end{abstract}

Ключові слова: віддалені наслідки легкої закритої черепно-мозкової травми, патогенез, метаболічні порушення, перекисне окиснення ліпідів, антиоксидантна система.

Останнім часом активно обговорюється роль метаболічних та біоенергетичних порушень у формуванні різних психоневрологічних синдромів у хворих із віддаленими наслідками після перенесеної легкої закритої черепно-мозкової травми (3ЧМТ) [1-5].

Багатьма зарубіжними та вітчизняними дослідниками [4, 6-9] показано, що у віддалений період легкої ЗЧМТ порушується не тільки метаболічний гомеостаз, а також розвиваються ті чи інші біоенергетичні розлади. Ці патогенетичні зміни взагалі призводять до порушення рівноваги між діяльністю кори, підкоркових частин та ретикулярної формації стовбура головного мозку, що активно діють у механізмах формування посттравматичного неврологічного дефіциту. Комплекс психоневрологічних симптомів та інших розладів, які виникають через декілька тижнів, місяців або навіть років після перенесеної ЗЧМТ, прийнято називати віддаленими наслідками $[6,7,10]$. Одним із облігатних синдромів у клінічній структурі віддалених наслідків легкої зЧМТ $\epsilon$ посттравматичний синдром вегетативної дистонії із залученням як надсегментарного, так і сегментарного рівнів вегетативної нервової системи (ВНС), де травматичне пошкодження голови виступає провокуючим фактором щодо виникнення різноманітних вегетативних розладів. При аналізі клініко-симптоматичних проявів щодо ураження центральної або периферичної нервової системи найчастішою скаргою у хворих цієї категорії $\epsilon$ головний біль; з прямих наслідків легкої зЧМТ найчастіше відмічають церебрально-вогнищевий та астенічний синдроми, а також гідроцефалію та гіпертензивний синдром [1, 10-14].

В Україні та за кордоном проводиться комплексне та удосконалене дослідження патогенезу віддалених наслідків 3ЧМТ [5, $10,13,15-17]$, де особлива увага на сьогодні приділяється метаболічним змінам, особливостям перекисного окиснення ліпідів (ПОЛ) та глутаматексайтному дисбалансу як універсальним патогенетичним механізмам пошкодження клітинних мембран, тому що пояснити тільки окремим механічним пошкодженням розвиток основних психоневрологічних синдромів у посттравматичний період не $\epsilon$ до кінця можливим. Однак клініко-патогенетичні механізми при віддалених наслідках легкої ЗЧМТ залишаються не до кінця вивченими.

У розвитку посттравматичної патології та вторинних змін у хворих, що зазнали ЗЧМТ, як у гострий, так й у віддалений період деякими дослідниками відмічена висока активність вільнорадикальних перекисно-окиснювальних процесів [18, 19]. Ті самі процеси, але меншою мірою й більш тривалі, виявлені також у хворих, що зазнали легкої ЗЧМТ $[9,20,21]$. У ряді досліджень доведено, що основною ініціальною ланкою ураження нейрональних мембран та аксонів при нейротравмі $\epsilon$ не тільки факт отримання саме травми, але й посилення ПОЛ [5]. Отже, відомо, що процеси ПОЛ здійснюються за рахунок вільнорадикального окиснення органічних речовин молекулярним киснем, де окисненню піддаються переважно ненасичені жирні кислоти, такі як ліноленова, лінолева, арахідонова та ін., і тим швидше, чим вищий ступінь їх ненасиченості [22]. Внаслідок цього в організмі утворюються первинні продукти ПОЛ: радикали жирних кислот, гідроперекиси, дієнові кон'югати. Повторна радикальна атака з приєднанням до фосфоліпідів кисню призводить до утворення малонового діальдегіду - кінцевого продукту пол.

Вільнорадикальний процес окиснення здійснюється в нормі в усіх тканинах та $\epsilon$ важливою ланкою загального метаболізму, причому низькі концентрації перекисів та гідроперекисів $\epsilon$ необхідними для транспорту електронів, синтезу білків, жирів, нуклеотидів, простагландинів, диференціації клітин, фагоцитозу та $\epsilon$ фізіологічними для організму [2, 23, 24]. При цьому процеси ПОЛ контролюються антиоксидантною системою, яка включає специфічні ферменти, локалізовані у місцях можливого накопичення активних інтермедіаторів (каталази, пероксидази, цитохромоксидази, супероксиддисмутази) та широкий спектр водо- та жиророзчинних антиоксидантів (токофероли, вітамін А, убіхінон, стероїдні гормони), а також сполуки, які виявляють при певних умовах антиоксидантну активність.

Багато авторів вважають, що неконтрольована інтенсифікація ПОЛ відбувається в умовах порушення рівноваги між процесами пероксидації та активністю антиоксидантної системи [6, 7, 18, 25-27]. Таким чином, порушення балансу між вільнорадикальним окисненням та антиоксидантною системою призводить до розвитку в організмі оксидативного стресу з накопиченням надмірної кількості вільних радикалів, які викликають зміну будови та властивостей ліпідного шару зовнішніх та внутрішніх клітинних мембран, підвищують ї̈ неспецифічну проникність для іонів кальцію та інших іонів, інактивуючи мембранозв'язані ферменти. Ці ефекти відіграють важливу роль при ураженні центральної нервової системи (ЦНС) та формуванні неврологічного дефіциту у віддалений період ЗЧМТ [28].

Важливе значення у посиленні ПОЛ при будь-якій патології мають насамперед перенапруження та/або виснаження деяких ланок антирадикальної системи, таких як глутатіон, SH-група та ряд ферментів (каталази) [10, 15, 16, 29]. У зв'язку з цим особливий інтерес викликає вивчення стану ще одного важливого компонента антиоксидантної системи: пулу вітамінів-антиоксидантів (а-токоферолу 
та ретинолу), які знешкоджують вільні радикали у жировому шарі клітинних мембран, та вітаміну С, який чинить антиоксидантну дію у внутрішніх та міжклітинних рідинах $[22,30,31]$.

Згідно із сучасними даними в організмі людей та тварин з усіх токоферолів найбільш біологічно активним $\epsilon$ саме а-токоферол, молекули якого локалізуються на внутрішніх мембранах мітохондрій $[32,33]$. Саме він і вітамін С $€$ донаторами водневих іонів й обмежувачами вільнорадикальних реакцій. Вони беруть участь майже в усіх антирадикальних реакціях організму, при цьому а-токоферол перетворюється на радикал, який може у подальшому реагувати з іншими перекисними радикалами, внаслідок цього утворюються нерадикальні з'єднання; а-токоферол стабілізує мембранні структури, в яких відбуваються процеси вільнорадикального окиснення, підтримує функціональну цілісність зовнішньої цитоплазматичної мембрани клітини, пригнічує утворення ліпоперекисів, розриває ланцюги вільнорадикального окиснення шляхом нейтралізації вільних радикалів в момент їх створення [4, 7, 11, 34]. Таким чином, a-токоферол, який розташований у ліпопротеїновому шарі клітинних мембран нейронів та захищає клітинні мембрани від ПОЛ, $\epsilon$ головним жиророзчинним антиоксидантом в організмі людини.

Ретинол (вітамін А) як антиоксидант гальмує перетворення сульфгідрильних груп у дисульфідні і може брати участь в окисновідновних реакціях завдяки наявності подвійних зв'язків у своєї молекулі, здатності зв'язувати перекиси, які підвищують швидкість окиснення інших з'єднань. Ретинол також $\epsilon$ структурним компонентом клітинних мембран та забезпечує антиоксидантний захист всього організму $[3,24]$. Антиоксидантну дію вітаміну А пояснюють також його участю в обміні тіолових сполук, нормалізацією функціонально-структурних властивостей мембран, окисненням проміжних продуктів вітаміну А при високому вмісті кисню, що також може мати прооксидантні властивості $[32,34]$. Встановлено, що $\beta$-каротин, який $\epsilon$ провітаміном ретинолу, виявляє найвищу антиоксидантну активність при низькому парціальному тиску крові та витрачається при знешкодженні оксидованих ліпопротеїдів низької щільності [19, 22, 32, 34]. Вітаміни C, Е, $\beta$-каротин становлять так звану антиоксидантну вітамінну групу.

Однією 3 основних властивостей вітаміну $C \in$ його здатність до окисно-відновних перетворень, внаслідок чого він здатний бути окиснюваним до дегідроаскорбінової кислоти та разом з нею являє собою окиснювально-відновну систему $[9,17]$. Як важливий компонент біологічної антиоксидантної системи вітамін С пов'язаний з глутатіоном та токоферолом. Він бере активну участь у мікросомальному окисненні ендогенних та чужорідних речовин, стимулює активність цитохромної ланки, процеси гідроксилювання [31, 35, 36]. Від забезпеченості вітаміном С залежать активність цитохрому P450, фагоцитарна активність нейтрофілів та макрофагів, їх антимікробні властивості. Вітамін С $\epsilon$ потужним антиоксидантом та синергістом $\beta$-каротину й а-токоферолу, його дефіцит в організмі призводить до зниження антиоксидантного захисту організму в цілому та порушення синтезу колагену. Вітамін С бере участь у виробленні енергії, що $\epsilon$ необхідною для синтезу інтерферонів та інших цитокінів, підвищує протиокиснювальну активність вітаміну Е та являє собою першу лінію захисту в організмі від дії різних вільних радикалів й інших окиснювачів. Він пригнічує ПОЛ, хоча основну роль в цьому відіграє а-токоферол, нейтралізує окиснювачі, редукує канцерогенні нітроаміни $[8,37,38]$.

Антиокиснювальна система обриває процеси пероксидації, якщо остання стає надмірною. Однак в умовах недостатності антиоксидантної системи процеси ПОЛ стають посиленими та неконтрольованими, що призводить до накопичення надмірної кількості перекисів та продуктів вільнорадикального окиснення, які, вступаючи до реакції з фосфоліпідами нейромембран, призводять до структурних змін в них, внаслідок чого відбуваються збіднення мембран фосфоліпідами, порушення їх проникності та втрата пластичних властивостей з послідовним формуванням неврологічного дефіциту [15, 24].

Морфологічним наслідком такого окиснення ліпідів нейромембран $\epsilon$ формування полярних каналів проникності, що підвищує пасивну проникність мембран для іонів $\mathrm{Ca}^{2+}$, надлишок якого депонується у мітохондріях та призводить до порушення водноіонного гомеостазу клітини, розвитку енергетичного дефіциту та іï подальшої атрофії або загибелі [33]. Функціональна інтеграція нервової системи залежить від стану фосфоліпідних клітинних мембран, які $є$ дуже чутливими до навіть незначних змін ПОЛ та накопичення у плазмі крові та нервовій тканині токсичних кінцевих продуктів пероксидації [21, 39].

ЗЧМТ являє собою тяжку стресову дію, в умовах якої при пошкодженні головного мозку розвивається стресреалізуюча реакція ендокринної системи, що супроводжується багатьма комплексними психоневрологічними розладами, у тому числі активацією симпато-адреналової системи [28], що також $є$ одним із патогенетичних механізмів формування функціональних неврологічних синдромів на тлі віддалених наслідків легкої ЗЧМТ. Все вищенаведене необхідно враховувати при ранній діагностиці цієї патології.

Останніми роками збільшується кількість експериментальних робіт, що показують патогенетичну роль та провідне значення активізації симпато-адреналової системи, яка супроводжується змінами у продукції та дії катехоламінів при розвитку стресу, у тому числі при легкій зЧМТ [37]. Активізація симпато-адреналової системи бере участь у переключенні обмінних процесів на новий енергетичний рівень, а також у мобілізації механізмів адаптації та резистентності організму при дії патогенних факторів, формуванні неврологічних синдромів на тлі віддалених наслідків легкої ЗЧМТ. Деякими авторами достовірно встановлено, що рівень пероксидації завжди корелює з вмістом кортикостероїдів та катехоламінів у плазмі крові [11].

Згідно з даними дослідників $[15,19,24,26]$ одразу після ЗЧМТ відмічається активація ПОЛ за рахунок порушення процесів ферментативного окиснення та виходу із депо металів змінної валентності, які саме ії індукують, однак пригнічення ПОЛ за 24-48 год, що відмічається при стрес-реакціях, не виявлено, а, навпаки, відбувається активізація процесів пероксидації, яка відіграє провідну роль у розвитку гіпоксії головного мозку та його набряку, що має провідне клініко-патогенетичне значення у механізмах наступного розвитку різноманітних посттравматичних симптомів.

У патогенетичних механізмах перебігу віддалених наслідків ЗЧМТ одну з основних ролей відіграють також біохімічні зрушення в організмі, в першу чергу з боку нейромедіаторних глутаматергічних систем та амінокислотного обміну [23, 40, 41]. В експериментальних та клінічних роботах багатьох зарубіжних та вітчизняних дослідників показано, що глутамат, аспартат та гамма-аміномасляна кислота $€$ модуляторами не тільки судомної й нейропластичної активності головного мозку, вони прямо та опосередковано беруть участь у нейроексайтотоксичному процесі, регулюють основні процеси збудження та агресії, формування больового порогу, синаптичну пластичність, емоції, пам'ять [1, 3, 6, 24, 41]. При цьому одну з провідних ролей у механізмах декомпенсації перебігу віддалених наслідків нейротравми, на думку ряду авторів, відіграють судинні та аутоімунопатологічні процеси [7, 14, 36, 38].

У роботах деяких дослідників показано, що при легкій зЧМТ основним тригерним фактором щодо ініціації розвитку метаболічних та психоневрологічних змін нейрону $\epsilon$ порушення нейро- та гемодинаміки, що потім, в свою чергу, $\epsilon$ також додатковим ініціатором для інтенсифікації вільнорадикальних процесів [4, 8, 9]. При цьому показано фазність у накопиченні перекисних продуктів. Вважається, що первинна реакція накопичення перекисів може відбуватися безпосередньо після нейротравми. Потім, у разі стабілізації окиснювальних процесів відмічається відновлення рівнів ендоперекисів сироватки крові до інтактного рівня. У разі якщо стабілізації не досягнуто, наступні спалахи вмісту перекисів також можливі, тривала дестабілізація процесів пероксидації у нервовій тканині після легкої ЗЧМТ може бути причиною подальших спалахів накопичення перекисів та виснаження пулу антиоксидантного захисту нейронів $[15,37]$.

За результатами проведеного літературного аналізу встановлено, що процеси ПОЛ, які активізуються на тлі ЧМТ або ЗЧМТ, призводять до пошкодження структури мембран та метаболізму нейрону й глії, порушення мікроциркуляції. За даними деяких авторів, концентрація токсичних продуктів ПОЛ $\epsilon$ показником ступеня деструкції клітинних мембран [24]. 
Дані літератури щодо стану процесів ПОЛ на тлі формування віддалених наслідків легкої ЗЧМТ мають досить суперечливий характер; у ряді досліджень показано, що в організмі тварин з модельованою черепно-мозковою травмою відзначається зниження процесів пероксидації $[22,38]$. На наш погляд, ця суперечливість отриманих результатів може бути обумовлена особливостями способу моделювання нейротравми та експериментальної гіпоксії. Поряд $з$ цим клінічний досвід показує, що будь-яка черепно-мозкова травма не проходить без наслідків та вони вперше можуть проявлятися через багато років $[6,7,40]$.

В експериментальних працях переважно зарубіжних дослідників виявлено значні зміни функціональної активності ферментів антиоксидантного захисту та інтенсивності ПОЛ порівняно 3 аналогічними показниками нетравматизованих щурів $[19,23,36]$. Вiдомо, що занадто сильна активація процесів вільнорадикального окиснення призводить до вираженої гіпоксії мозкової тканини, поперше, за рахунок надмірної утилізації кисню, по-друге, внаслідок розриву процесів ферментативного окиснення за рахунок пригнічення активності дегідрогеназ, утворення токсичних кінцевих продуктів пероксидації, що, в свою чергу, знову її активує. Інтенсифікація процесів ПОЛ призводить до порушення ультраструктури мітохондрій нейронів [33].

Дані літератури щодо стану процесів ПОЛ у хворих з віддаленими наслідками легкої ЗЧМТ отримані, як правило, в експерименті. В експериментальних роботах насамперед зарубіжних дослідників встановлено, що значне зростання рівня ПОЛ у тканині мозку щурів пригнічує активність ензиму мітохондріальної сукцинатдегідрогенази, механізм гальмування якої може бути одним з трьох: зміна складу фосфоліпідного компонента мембран, модифікація білкових молекул ферментів за рахунок окиснення їх тіолових груп, взаємодія продуктів ПОЛ з вільними аміногрупами білків ензимів. Все це може бути тісно пов'язане з ураженням мембранно-клітинних структур нейронів навіть при легкій 3ЧМТ $[27,39]$.

Таким чином, вивчення патогенетичних механізмів метаболічних порушень та функціонального стану ПОЛ при формуванні віддалених наслідків легкої ЗЧМТ, а також визначення однієї 3 провідних ролей оксидантно-антиоксидантних взаємовідносин у розвитку енергетичного дефіциту та пошкодженні ЦНС у посттравматичний період $\epsilon$ актуальним науковим та клініко-експериментальним напрямком.

\section{Конфлікт інтересів: відсутній. \\ Conflict of interests: the author declares no conflict of interests.}

\section{Список використаної літератури/References:}

1. Korostiy V.I., Polishchuk V.T., Zavorotny V.I. (2015) Psychopharmacotherapy in the complex treatment and rehabilitation of post-traumatic stress disorder. Int. Neurol. J., 6(76): 59-71. (In Ukr.).

2. Brigode W., Cohan C., Beattie G., Victorino G. (2019) Alcohol in Traumatic Brain Injury: Toxic or Therapeutic? J. Surg. Res., 244: 196-204.

3. Jenner P. (1994) Oxidative damage in neurodegenarative disease. Lancet, 344(8925):796-798. doi: 10.1016/50140-6736(94)92347-7

4. Khatri N., Thakur M., PareekV. et al. (2018) Oxidative stress: major threat in traumatic brain injury. CNS Neurol. Disord. Drug Targets, 17(9): 689-695.

5. Lekomtseva Ye.V. (2019) The increased kinetics of $\mathrm{H}_{2}, \mathrm{O}_{2}$-induced chemiluminescence in the patients with long-term consequences after cerebral contusion. Modern medical technologies, 4:21-26.

6. Bogolepova A.N., Chukanova E.I. (2010) The problem of neuroplasticity. Int. Neurol. J., 8(38): 69-72. (In Rus.).

7. Yakhno N.N., Shtulman D.R. (Eds.) (2001) Diseases of the nervous system. Medicine, Moscow, 480 p. (In Rus.).

8. Kozlov A.V., Bahrami S. Redl H., Szabo C. (2017) Alterations in nitric oxide homeostasis during traumatic brain injury. Biochim. Biophys. Acta Mol. Basis Dis., 1863: 2627-2632.

9. Lekomtseva Ye.V. (2019) Some metabolic processes in the patients with long-term consequences of mild traumatic brain injury. Int. J. Med. Medical Res., 5(2): 25-31.

10. Polishchuk M.E., Goncharuk 0.M. (2015) Closed traumatic brain injury. A modern view of the problem. Int. Neurol. J., 6(76): 72-80. (In Ukr.).

11. Vein A.M. (Ed.) (2000) Autonomic disorders: clinical presentation, diagnosis, treatment. Medical news agency, Moscow, $752 \mathrm{p}$.
12. Lekomtseva Ye.V. (2019) The content of tau protein in the serum of patients with long-term consequences of mild traumatic brain injury. Ukr. Neurol. J., 1(50): 17-20. (In Ukr.).

13. Moroz V.V., Carmen N.B., Mayevsky E.I. (2011) Mechanisms of secondary neuronal damage in traumatic brain injury. General Reanimatol., 7: 42-45. (In Rus.).

14. Samuels M. (Ed.) (1997) Neurology (transl. from English). Practice, Moscow, 638 p. (In Rus.).

15. Awasthi D., Church D.F., Torbati D. et al. (1997) Oxidative stress following traumatic brain injury in rats. Surg. Neurol., 47(6): 575-581.

16. Bazan N.G. (1999) Second messengers derived from excitable membranes are involves in ischemic and seizure-related brain damage. Path. Physiol. Exper. Ther., 4: 11-16.

17. Li X., Wang H., Wen G. et al. (2018) Neuroprotection by quercetin via mitochondrial function adaptation in traumatic brain injury: PGC-1a pathway as a potential mechanism. J. Cell Mol. Med., 22(2): 883-891.

18. Mayer E.A. (2003) Dissecting the components of central response to stress. Nature Neurosci., 6: 1011-1107.

19. Zhao Y.J., Lei S., Lin X. et al. (2011) 4-hydroxybenzyl alcohol ameliorates cerebral injury in rats by antioxidant action. Neurochem. Res., 36(2): 339-346.

20. Martin L.J., Wong M., Hanaford A. (2019) Neonatal brain injury and genetic causes of adultonset neurodegenerative disease in mice interact with effects on acute and late outcomes. Front. Neurol., 10: 635

21. Sohal R.S. (2002) Role of oxidative stress and protein oxidation in the aging process. Free Radic. Biol. Med., 33(1): 37-44.

22. Xia D., Zhai X., Wang H. et al. (2019) Alpha lipoic acid inhibits oxidative stress-induced apoptosis by modulating of $\mathrm{Nrf}_{2}$ signalling pathway after traumatic brain injury. J. Cell Mol. Med., 23(6): 4088-4096.

23. DorsettC.R., McGuire J.L., DePasquale E.A et al. (2017) Glutamate neurotransmission in rodent models of traumatic brain injury. J. Neurotrauma, 15(34): 263-272.

24. Halliwell B., Gutteridge J.M. (1984) Lipid peroxidation, oxygen radicals, cell damage, and antioxidant therapy. Lancet, 1(8391): 1396-1397. doi: 10.1016/50140-6736(84)91886-5

25. Linden D.E. (2005) Where in the brain is it produced and what does it tell us? Neuroscientist, 11: $563-576$

26. McGinn M.J., Povlishock J.T. (2016) Pathophysiology of traumatic brain injury. Neurosurg. Clin. N. Am., 27(4): 397-407.

27. Phillips L.L., Reeves T.M. (2001) Interactive pathology following traumatic brain injury modifies hippocampal plasticity. Restor. Neurol. Neurosci., 19(3-4): 213-235.

28. Vespa P.M., McArthur D.L., Xu Y. et al. (2010) Nonconvulsive seizures after traumatic brain injury are associated with hippocampal atrophy. Neurology, 75(9): 792-798.

29. Morris M.C., Bercz A., Niziolek G.M. et al. (2019) UCH-L1 is a poor serum biomarker of murine traumatic brain injury after polytrauma. J. Surg. Res., 244: 63-68.

30. Neuberger E.J., Wahab R.A., Jayakumar A. et al. (2014) Distinct effect of impact rise times on immediate and early neuropathology after brain injury in juvenile rats. J. Neurosci. Res., 92(10): 1350-1361.

31. Perkin G.D. (2002) Neurology in general practice. The United Kingdom, Dunitz Ltd., 90 p.

32. Yao M., Yang L., Wang J. et al. (2015) Neurological recovery and antioxidant effects of curcumin for spinal cord injury in the rat: a network meta-analysis and systematic review J. Neurotrauma, 32(6): 381-391.

33. Zhang L., Wang H., Zhou X. et al. (2019) Role of mitochondrial calcium uniporter-mediated $\mathrm{Ca}^{2+}$ and iron accumulation in traumatic brain injury. J. Cell Mol. Med., 23(4): 2995-3009.

34. Youn Y.K., LaLond C., Demling R. (1991) Use of antioxidant therapy in shock and trauma. Circ. Shock, 35(4): 245-249.

35. Rattan S.I. (2006) Theories of biological aging: genes, proteins and free radicals. Free Radic. Res., 40(12): 1230-1238.

36. Zhang H., Adwanikar H., Werb Z., Noble-Haeusslein L.J. (2010) Matrix metalloproteinases and neurotrauma: evolving roles in injury and reparative processes. Neurosci., 16(2): $156-170$.

37. Wang W.T., Sun L, Sun C.H. (2019) PDIA -regulted inflammation and oxidative stress contribute to the traumatic brain injury (TBI) in mice. Biochem. Biophys. Res. Commun., 518(4): 657-663.

38. Zeng Z., Zhang Y., Jiang W. et al. (2019) Modulation of autophagy in traumatic brain injury. J. Cell Physiol. doi: 10.1002/jp. 29173

39. Phillips L.L., Lyeth B.G., Hamm R.J., Povlishock J.T. (1994) Combined fluid percussion brain injury and entorhinal cortical lesion: a model for assessing the interaction between neuroexcitation and deafferentation. J. Neurotrauma, 11(6): 641-656.

40. Lekomtseva Ye.V. (2019) Clinical and neurological features and the content of neuroamino acids in patients with long-term consequences of mild closed traumatic brain injury. Int. Neurol. J., 3(105): 33-38. (In Ukr.).

41. Papa L., Ramia M.M., Edwards D. et al. (2015) Systematic review of clinical studies examining biomarkers of brain injury in athletes after sports-related concussion. J. Neurotrauma, 32(10): $661-673$. 


\section{Modern view on pathogenetic mechanisms of long-term consequences forming following mild traumatic brain injury}

\section{Ye.V. Lekomtseva}

State Institute of Neurology, Psychiatry and Narcology of the National Academy of the Medical Sciences of Ukraine, Kharkiv, Ukraine

Abstract. The article was devoted to the study of the complex pathogenetic mechanisms of metabolic changes and bioenergetic disturbances in long-term consequences following mild traumatic brain injury. It was presented the modern view and general data according to etiopatho- genesis, pathomorphology and the peculiarities of the neurochemistry of any metabolic disturbances, in particular, clinical and experimental data about the functional state of free radical peroxidation of lipids, glutamate and antioxidative systems in this category of the patients, presented the modern principles of early diagnostics of this pathology. The mechanisms of development of uncontrolled intensification of lipid peroxidation, which occurs in conditions of imbalance between peroxidation processes and the activity of the antioxidant system, are considered. The available studies also demonstrate the high importance of oxidant-antioxidant relationships in the formation of energy deficiency and damage to neuronal membranes in the long term after neurotrauma.

Key words: long-term consequences following mild traumatic brain injury, pathogenesis, metabolic disturbances, lipid peroxidation, antioxidative system.

Відомості про автора:
Лекомцева Євгенія Володимирівна — кандидат медичних наук, лікар-невропатолог, лікар-психіатр, про-
відний науковий співробітник відділення функціональної нейрохірургії з групою патоморфології Державної
установи «Інститут неврології, психіатрії та наркології Національної академії медичних наукУкраїни», Харків,
Україна.
Адреса для кореспонденції:
Лекомцева Євгенія Володимирівна
61068, Харків, вул. Академіка Павлова, 46
Е-mail: yevgeniyalekomtseva@gmail.com

Відомості про автора:

Information about the author:

Lekomtseva Yevgeniya V. - MD, PhD, Leading researcher of the Department of Functional Neurosurgery with the group of pathomorphology of the State Institution «Institute of Neurology, Psychiatry and Narcology of the National Academy of the Medical Sciences of Ukraine», Kharkiv, Ukraine.

\section{Address for correspondence:}

Yevgeniya Lekomtseva

61068, Kharkiv, Academic Pavlov str., 46

E-mail: yevgeniyalekomtseva@gmail.com

Надійшла до редакції/Received: 02.04.2021

Прийнято до друку/Accepted: 21.04.2021 